DOI 10.18551/rjoas.2021-07.01

\title{
RATIO LEGIS REGULATION OF POLITICAL RIGHTS OF PERSONS WITH DISABILITIES IN LAW NUMBER 7 OF 2017 CONCERNING GENERAL ELECTIONS
}

\author{
Lobo Ferdinandus Ngau* \\ Lecturer at Faculty of Law, Widya Mandira Catholic University, Kupang \& Doctoral Candidate \\ at Faculty of Law, University of Brawijaya, Malang, Indonesia
}

Istislam, Widiarto Aan Eko, Widagdo Setyo, Lecturers

Faculty of Law, University of Brawijaya, Malang, Indonesia

*E-mail: ferdinandlobo21@gmail.com

\begin{abstract}
The purpose of writing this article is to examine more deeply what constitutes the basic considerations, objectives, legal arguments, and reasons for the formulation of political rights for persons with disabilities as stated in Article 5 of Law Number 7 of 2017 concerning General Elections. Judging from the material of the legislation, the Act does not provide legal justice, legal benefits, or legal certainty in the protection, respect, enforcement, and fulfillment of the political rights of persons with disabilities to be elected as candidates for members of the People's Representative Council (DPR) or Regional People's Representative Council (Provincial or Regency/City DPRD). The advantage of this article is that researchers offer to problem-solve in the formulation of the Draft Law on Elections to construct nondiscriminatory vulnerable groups, which include women's groups and groups of people with disabilities. The drafters of the Election Law must consider the level of vulnerability of each group and then align it with appropriate policies in the form of relevant affirmative actions. In addition, there is a need to participate in vulnerable groups and NGOs engaged in empowering and advocating for the rights of persons with disabilities.
\end{abstract}

\section{KEY WORDS}

Ratio legis, political rights, persons with disabilities, vulnerable groups, general election.

The principles of democracy and citizen participation in government are closely intertwined with the realization of political rights. Political rights have an expansive meaning, namely the right to organize, specifically about political rights, which include the right of citizens to participate in general elections according to the 1945 Constitution of the Republic of Indonesia. Political rights in general elections are referred to as suffrage which consists of active suffrage and passive suffrage (Kansil, 1985). The right to vote and be elected is regulated and recognized in the 1945 Constitution of the Republic of Indonesia, namely Article 27 Paragraph (1), Article 28 D Paragraph (3), Article 28 E Paragraph (3).

In principle, the political right to be elected in general elections is a constitutional right for everyone to be protected and fulfilled without any discrimination. The political rights of citizens are emphasized in Law Number 39 of 1999 concerning Human Rights. Article 43 paragraph (1) states that every citizen has the right to be elected and vote in general elections based on equal rights through direct, general, free, secret, honest, and fair voting according to the provisions of the legislation.

In the realization of political rights, not everyone can access and exercise these rights freely and fairly. To fulfill the political rights of persons with disabilities, Article 5 of Law Number 7 of 2017 concerning General Elections (hereinafter referred to as 2017 General Election Law) confirms that persons with disabilities who meet the requirements have the same opportunities as voters and are elected as candidates for Members of the DPR, as a candidate for members of the DPD, as a candidate for President/Vice President, as a candidate for members of the DPRD, and as an election organizer". 
The political right to vote and be elected in general elections is regulated in the 2017 General Election Law. As citizens, persons with disabilities also have the same rights as other citizens who are non-disabled. The phrase "persons with disabilities who meet the requirements have the same opportunity as voters and are elected as candidates for members of the DPR...", it shows that there is progress regarding the recognition of political rights (right to vote and the right to be elected as members of the legislature) for persons with disabilities. It can be said that based on the Election Law, persons with disabilities will be guaranteed to exercise their political rights to vote and be elected as members of the legislature based on the principles and objectives of the General Election as stated in Articles 3 and 4 of the 2017 General Election Law.

However, the 2017 General Election Law only provides equal opportunities for persons with disabilities and other citizens who normally compete in the political contestation of the General Election. So, according to this law, persons with disabilities are seen as having in common similarity with other citizens who in turn receive equal treatment (equal treatment) in realizing their democracy (political rights). This is because people with disabilities have experienced discrimination in various aspects of life for a long time, including discrimination in realizing their political rights.

As for women's groups, the 2017 General Election Law is very responsive to protecting women's political rights through special treatment. The special affirmative action treatment regulated in the law is contained in the provisions of the article. As women who have been included in the category of marginal groups or vulnerable groups whose rights have been neglected, they get affirmative action to reduce gender inequality in the election contestation by determining a minimum quota of $30 \%$ of candidates for members of the DPR RI and DPRD. However, this treatment is not given to persons with disabilities. Persons with disabilities do not get legal protection to access and fulfill their political rights to become members of the people's representative institutions.

The 2017 General Election Law has specifically regulated the political rights of persons with disabilities as stated in Article 5 of the Law. To understand a law In reviewing a law a law and interpreting its norms, of course, it is necessary to understand the reason or purpose why the law was drafted or formulated. To understand the basis for formulating legal norms in law, the most essential thing that needs to be studied and understood is the ratio legis.

Ratio legis is a thought that forms the philosophical basis or is contained behind the law (Marzuki, 2005). By examining the ratio legis of a law, we can examine or examine: first, the Minutes of Discussion on the Draft Law; second, reviewing the Academic Paper of the Draft Law and/or analyzing the "considering" section and the specific objectives of a law and other norms contained in the Act.

\section{METHODS OF RESEARCH}

This type of research is normative legal research. According to Peter Mahmud Marzuki, legal research is a process to find the rule of law, legal principles, and legal doctrines to answer the legal issues faced (Marzuki, 2005). The approach method used in this research is adapted to the type of research conducted where this research is normative legal research (Marzuki, 2005). The approach in conducting research using the statute approach.

\section{RESULTS AND DISCUSSION}

Ratio legis, as mentioned earlier, is the thought that forms the philosophical basis or is contained behind the law (Marzuki, 2005). Thus, studying the ratio legis of law, we can examine the Minutes of Draft Laws, Academic Papers on Draft Laws and/or investigate the "considering" part of a law which is then carried out in research using a legal approach.

The presence of the General Election Law is an order of the 1945 Constitution of the Republic of Indonesia. The realization of the objectives in the opening of the 1945 Constitution of the Republic of Indonesia and the values of justice and democracy in the 4th Precept of Pancasila, then conducted general elections for members of the House of 
Representatives, members of the Regional Representatives Council, President and Vice President, and to elect members of the Regional People's Representative Council. General elections are a means of realizing the people to produce people's representatives and a democratic state government based on Pancasila and the 1945 Constitution of the Republic of Indonesia.

The 2017 General Election Law is an embodiment of the principles of democracy with integrity. This is stated in the Preamble to the 2017 General Election Law letter b, which says that it is necessary to regulate general elections as the embodiment of a democratic state administration system with integrity to ensure consistency and legal certainty and effective and efficient general elections.

This provision is proof that elections are a place for the realization of a genuinely democratic system. As the 2017 General Election Law mandate emphasizes: to realize democratic elections with integrity, general elections must be held based on the principles or principles of implementing direct, general, free, secret, and fair elections. These election principles have been used since the reform era since the 1999 general election as stipulated in Law Number 3 of 1999 concerning General Elections.

Specifically, about the political rights of persons with disabilities, the 2017 Law on General Elections also regulates the right to vote and be elected as legislative members for persons with disabilities. This is stated in Article 5 of the General Election Law of 2017, which confirms that persons with disabilities who meet the requirements have the same opportunities as voters and are elected as candidates for members of the DPR, as candidates for members of the DPD, as candidates for President/Vice President, as candidates for members. DPRD, and as Election Organizers.

The phrase "persons with disabilities who meet the requirements have the same opportunity as voters and are elected as candidates for members of the DPR...", shows that there is progress regarding the recognition of political rights (right to vote and the right to be elected as members of the legislature) for persons with disabilities. It can be said that based on the Election Law, persons with disabilities will be given guarantees to exercise their political right to vote and be elected as members of the legislature based on the principles and objectives of the General Election as stated in Article 3 and the 2017 Law on General Elections. The 2017 General Election Law is the first general election law that explicitly regulates the political rights of persons with disabilities, particularly the right to be elected as members of the DPR or DPRD.

The formulation of norms regarding the political rights of persons with disabilities in the 2017 General Election Law is the implementation of Law Number 8 of 2016 concerning Persons with Disabilities as regulated in the Sixth Part concerning Political Rights of Persons with Disabilities as contained in Article 75 Paragraphs (1) and (2), Article 76 and Article 77.

In the provisions of Article 75 Paragraphs (1) and (2), there is a phrase "The Government, and Local Governments are obliged to guarantee" persons with disabilities can participate effectively in political and public life and guarantee the rights and opportunities for them to vote and be elected. Meanwhile, Article 76 regulates the rights of persons with disabilities to sit in government.

Furthermore, Article 77 regulates the obligations of the government and local governments to guarantee the political rights of persons with disabilities by taking into account the diversity of disabilities in general elections. And carry out all public functions at all levels of government.

It can be interpreted that Law Number 8 of 2016 concerning Persons with Disabilities instructs the Government and local governments to provide guarantees for the protection of the realization of the political rights of persons with disabilities. The political rights referred to by the Act are in the form of the right to sit in public positions either elected or through an appointment mechanism.

Thus, the regulation of the political rights of Persons with Disabilities in Article 5 of the 2017 General Election Law is an elaboration of the provisions of the 2016 Law on Persons with Disabilities, which explicitly regulates the political rights of persons with disabilities. Therefore, Law Number 8 of 2016 concerning Persons with Disabilities is an Umbrella Act or 
raamwet/mode wet of regulating the rights of persons with disabilities as regulated in other laws and regulations, including the Law on General Elections.

In other words, the Law on General Elections must regulate in more detail the protection, promotion, enforcement, and fulfillment of the political rights of persons with disabilities, especially the right to be elected as candidates for members of the DPR or DPRD.

However, the provisions in Article 5 of the General Election Law of 2017 have not fully protected the political rights of persons with disabilities to sit in public office, especially the right to be elected as candidates for members of the people's representative institutions. This provision only recognizes the existence of political rights of persons with disabilities to be selected as candidates for members of the DPR or other public positions.

The 2017 General Election Law only regulates equality of political rights in a general sense for persons with disabilities to realize their political rights. However, the equation for political rights for persons with disabilities is implicitly stated in the requirements for candidates for members of the DPR RI, Provincial DPRD, and Regency/Municipal DPRD as stipulated in Article 240 (1) of the 2017 General Election Law, which regulates and affirms:

Prospective candidates for members of DPR, Provincial DPRD, and Regency/Municipal DPRD are Indonesian citizens and must meet the following requirements:

- has reached the age of twenty-one years or more;

- fear God Almighty;

- residing in the territory of the Unitary State of the Republic of Indonesia;

- can speak, read, and/or write in Indonesian;

- with a minimum education of high school graduation, madrasah aliyah, vocational high school, vocational madrasah aliyah, or another equivalent school;

- loyal to Pancasila, the 1945 Constitution of the Republic of Indonesia, the Unitary State of the Republic of Indonesia, and Bhinneka Tunggal Ika;

- has never been sentenced to imprisonment based on a court decision that has obtained permanent legal force for committing a crime punishable by imprisonment of 5 (five) years or more, except for openly and honestly state to the public that the person concerned is a former convict;

- physically, mentally, and free from narcotics abuse;

- registered as a voter;

- willing to work full time;

- resign as regional head, deputy regional head, state civil servant, member of the Indonesian National Armed Forces, member of the Indonesian National Police, directors, commissioners, supervisory board and employees of state-owned enterprises and/or regionally-owned enterprises, or other entities the budget is sourced from state finances, which is stated in an irrevocable letter of resignation;

- willing not to practice as a public accountant, advocate, notary, land deed official, or not to do the work of providing goods and services related to state finances and other work that may cause a conflict of interest with the duties, authorities, and rights as a member of the DPR, Provincial DPRD and Regency/Municipal DPRD under the provisions of the legislation;

- willing not to hold concurrent positions as other state officials, directors, commissioners, supervisory boards and in state-owned enterprises and/or regionalowned enterprises and other entities whose budget is sourced from state finances;

- become a member of the Election Contesting Political Parties;

- nominated only in one representative institution and

- nominated only in one electoral district.

Although before the 2017 General Election Law formulation, Law Number 8 of 2016 concerning Persons with Disabilities. The law has regulated the obligations of the government and local governments to protect, fulfill and promote the political rights of persons with disabilities to be elected as candidates for members of the people's representative institutions (Article 75, and Article 77 letter e). However, the phrase 
"Government or Local Government is obligated to protect the political rights of persons with disabilities" in the Law on Persons with Disabilities is not further elaborated in the 2017 General Election Law.

Therefore, it is necessary to examine further the ratio legis regulating the political rights of persons with disabilities in Article 5 of the 2017 General Election Law, the primary considerations, reasons, and objectives for formulating the provisions of this article. While the provisions of Article 5 only regulate the general equality of rights. People with disabilities have experienced discrimination to access their political rights to be elected as legislative candidates.

The recognition of the political rights of persons with disabilities in the provisions of Article 5 of the 2017 General Election Law is an embodiment of the spirit of democracy and the rule of law. These two principles are contained in the Academic Manuscript of the Bill on the Implementation of Elections, which formulates the codification of the Law on Elections, among others, to create a democratic election law and legal certainty.

The principle of democracy is contained in the academic text of the Bill on Elections, namely the spirit to realize four democratic principles, including: "political rights of citizens related to elections, principles of democratic elections, elections with integrity and elections with justice".

The principle of the rule of law has been realized through the preparation of the Bill on General Elections because through the Bill:

- General elections can be formulated as competition between election participants or between pairs of candidates to fight for the same thing, namely the seat of state administration;

- Legal certainty ensures that all parties involved in organizing the election have the same understanding of the game's rules or election procedures and provide an independent KPU;

- The process of holding the stages of the election will democratically take place;

- Citizens' political participation in elections and law enforcement systems and election dispute resolution and law enforcement systems and election dispute resolution will be more secure.

The enforcement of human rights is an unbroken link between the principles of democracy, people's sovereignty, and the rule of law (Handoyo, 2009). The doctrine of human rights has been universally accepted as a moral, political, legal framework and a guideline in building a more peaceful world free from fear and oppression, and unfair treatment (Asshidiqie, 2012). From the previous illustration, there are so many theories about democracy that have been formulated by the authors, so that Robert Dahl, in his book $A$ Preface to Democratic Theory (1956), stated, "...there is no democratic theory - there are only democratic theories" (Rauf, 1998). Therefore, in understanding the rule of law, the guarantee of the legal protection of human rights is an absolute feature that must exist in every country. Thus, aspects of human rights are closely related to democracy, including (Fuady, 2010):

- There is the right to vote and be elected;

- The right to opinion and expression (freedom of expression);

- The right to association (freedom of assembly);

- There is a guarantee of a free press (freedom of the press);

- There is freedom of religion and freedom of religion;

- The existence of freedom to choose a job and seek the life desired by each community member.

There are two kinds of rights in the context of occupying positions in society, namely:

1. The right to vote and be elected is part of human rights;

2. One of the principles of human rights is equality before the law or nondiscrimination.

However, the authors agree that the democratic system is based on two basic concepts: freedom/equality and people sovereignty (Rauf, 1998). 
Ratio legis regulating the political rights of persons with disabilities as stipulated in Article 5 of Law Number 7 of 2017 concerning General Elections is closely related to the philosophical reasons for these provisions, namely the values contained in Pancasila. Therefore, according to the researcher, the presence of norms governing the political rights of persons with disabilities in Law Number 7 of 2017 is an elaboration of the basic principles of Pancasila.

This is reflected in the National Awakening Party Faction (FPKB) views presented by $\mathrm{H}$. Yanuar Prihatin at the 1st Working Meeting (Special Committee for Draft Law on Election Administration), on November 30, 2016, led by Lukman Edy. Yanuar Priahatin stressed (Sekretariat Jenderal DPR RI, 2017). The first most crucial guide is our ideal basis, meaning that we have agreed that Pancasila is a big idea, and of course, it must be the primary reference. The question is that this bill will strengthen Pancasila or will it even further distance this country and nation or this political system from Pancasila..."

The same thing was conveyed by Arif Wibowo (Indonesian Democratic Party of Struggle/FPDIP), who said (Sekretariat Jenderal DPR RI, 2017)... First, this country is based on Pancasila as an ideology. Therefore, every principle of Pancasila must be the basis as staatsfundamentalnorms in preparing this draft law.

Thus, in formulating the Draft Law on General Elections during the Second Session of the 2016-2017 Session Year, Pancasila was placed as a legal ideal (Rechtsidee). Theoretically, in line with the opinion of Otje Salman, he said that the constitutional imposition of the Pancasila precepts (constitutioneering) in the Preamble to the 1945 Constitution is an acknowledgment of Pancasila as a legal ideal (rechtsidee) the basis of the construction of thinking which is a necessity to direct the law to ideals. Ideals that the community wants and serves as a guide or guiding star (leitsiern) to achieve community goals (Soemadiningrat, 2002).

In the discussion of the Draft Law, Pancasila is the leitisiern or guiding star for the law to be in harmony with the values contained in Pancasila.

The presence of Article 5, which regulates the political rights of persons with disabilities, especially the right to be elected as members of the DPR and DPRD (Provincial and Regency/City) is closely related to the values contained in the Constitution of the Republic of Indonesia which is also the nation's view of life and is the philosophical foundation of the nation. Namely Pancasila.

Pancasila contained in the Preamble is a legal ideal (Rechtsidee) and is the source of all sources of law. Thus, the democracy that should be applied in the contestation of the general election is Pancasila democracy, where the general election is carried out by upholding the values of Pancasila in an integrative, fair, and non-discriminatory manner.

From a democratic perspective, Indonesia has a special character as a country that adheres to Pancasila democracy. Therefore, Usep Ranawidjaja elaborated on the mechanism of Pancasila democracy. In the second National Law Seminar in December 1968 in Semarang, Usep Ranawidjaja, quoted by Sri Sumantri, raised four essential elements with the Pancasila democracy mechanism, namely (Sumantri, 1969):

1. The belief that the state of society is always changing and moving towards a more advanced direction;

2. The belief that changes in society occur because of encouragement rather than human actions, and therefore, humans can and must act to form a more advanced situation;

3. The belief that there must be tolerance, concession, and mutual giving in the life of society/state. In this regard, there must be a willingness to give trust (mandate) to other parties to exercise power/leadership within a certain period;

4. Belief in the truth of common sense, namely that in the end, it is common sense that will achieve victory over unhealthy reason.

Recognition and respect for the political rights of persons with disabilities to become members of the DPR and DPRD, according to the researchers, implement the values of the Pancasila Philosophy, namely: 
- The fourth precept is about democracy led by wisdom/representation. The embodiment of the 4th precept is the embodiment of democracy itself which in the context of the Unitary State of the Republic of Indonesia recognizes representative democracy through representative institutions both at the center and in the regions, namely the DPR and DPRD. Persons with disabilities have the same human rights and dignity as other people, so they should be allowed to have access to become members of representative institutions;

- The embodiment of the second principle of Pancasila, namely "just and civilized humanity". First, the recognition of the political rights of persons with disabilities to become members of the people's representatives is a form of respect for the value of the second precept in the form of acknowledging the political rights of persons with disabilities to become members of the people's representatives, namely members of the DPR and DPRD. Second, rejecting discriminatory behavior towards access to the political rights of persons with disabilities to become members of the people's representatives;

- The realization of the 3rd principle of Indonesian unity. Through recognition of the political rights of persons with disabilities, fostering a spirit of kinship and a culture of mutual respect will lead to the creation of unity for all elements of the nation as a whole. Recognition of the political rights of persons with disabilities further strengthens the spirit of the 3rd principle, namely the unity of Indonesia;

- Precept 5, Social Justice for all Indonesian people. Recognition of the political rights of persons with disabilities as stated in Article 5 paragraphs (1) and (2) of Law Number 7 of 2017 is a spirit of the embodiment of the principles of equality and social justice as enshrined in the 5th precept of Pancasila.

The principle of egalitarianism or the principle of equality of rights has been enshrined in the provisions of the 1945 Constitution of the Republic of Indonesia. It has become the rationale for formulating Article 5 paragraphs (1) and (2) of Law Number 7 of 2017 concerning Persons with Disabilities. This can be seen in the provisions of Article 27 paragraph (1) of the 1945 Constitution of the Republic of Indonesia, which affirms: "All citizens are equal before the law and government and are obliged to uphold the law and government without exception". This provision is a spirit that all people without discrimination have equality before the law and government. "Government" is meant by the 1945 Constitution of the Republic of Indonesia as government in a broad sense, namely executive, judicial and legislative powers. Thus, everyone has the equal right to be involved in the administration of the state, including to become a member of the representative body to exercise legislative power. Our constitution has given recognition of the equal rights of all citizens regardless of ethnicity, religion, race, or special circumstances such as disability. The equality of rights referred to by the 1945 Constitution of the Republic of Indonesia covers various aspects of life, including political rights, further elaborated in the 2017 General Election Law.

The general election is the implementation of popular sovereignty indirectly electing the President/Vice President, Members of the MPR, DPR, DPD, and DPRD, which are carried out directly, publicly, freely, confidentially, honestly, and fairly. This spirit is contained in Article $22 \mathrm{E}$ of the 1945 Constitution of the Republic of Indonesia. General elections also provide equal space in competing for the people's votes. As conveyed by the Minister of Home Affairs Tjahjo Kumolo in the 1st Working Meeting of the Special Committee of the DPR for the Election Implementation Bill, the Second Session Period with the Chairperson of the Meeting H.M. Lukman Edy (F-PKB), as follows (Sekretariat Jenderal DPR RI, 2016):

...Article 22 E paragraph (1) of the 1945 Constitution that to elect the President/Vice President, Members of the MPR, DPR, DPD, and DPRD through direct, general, free, secret, honest, and fair elections in every once every five years... the general election so far has provided more space for equality in the competition for the people's votes. The election is the implementation of people's sovereignty as stated by the 1945 Constitution of the Republic of Indonesia... Government is simple. The President's direction to us is only one, sovereignty is 
in the hands of political parties. Pay attention to it, don't ignore it. But the aspirations of the people are also accommodated...".

Similarly, the Minister of Law and Human Rights (Yasona Laoly) said (Sekretariat Jenderal DPR RI, 2016):

"Government: "...if we look at the constitutions of election participants, DPR election participants, DPRD are political parties. The Minister said earlier, "sovereignty of political parties". Even the President's nomination must also go through a political party or a coalition of political parties. So the strengthening of political parties as a vehicle for the recruitment of political elites must be affected in it." In today's open system, the winner takes all. Some do not reach the BPP (general election divisor number) because only reaching 15 thousand can beat all...".

What was conveyed by the Minister of Home Affairs and the Minister of Law and Human Rights showed the same spirit, namely to realize the principles of equality and nondiscrimination in the recruitment of candidates for legislative members (DPR or DPRD).

As the highest legislation, the 1945 Constitution of the Republic of Indonesia highly upholds respect, protects the fulfillment of rights, and strongly opposes discriminatory behavior that violates human dignity. This can be found in the provisions of Article 28 I paragraph (2), which emphasizes that everyone has the right to be free from discriminatory treatment on any basis and is entitled to protection against discriminatory treatment.

To ensure the protection of human rights for every citizen, including persons with disabilities, it is further emphasized in Article 28 I paragraph (4) of the 1945 Constitution of the Republic of Indonesia, which affirms that the protection, promotion, enforcement, and fulfillment of human rights are the responsibility of the state, especially the government.

The importance of formulating the political rights of persons with disabilities in the 2017 General Election Law is closely related to long-standing discrimination in the form of exclusion, namely discrimination by not including them in various aspects of life, including aspects of political life. According to Erlich Stereotype, this is closely related to the stereotyped attitude, which is a set of discretion and disability about any group of people (William, 1973). This means trust and distrust of specific community groups due to differences in status, ethnic culture, religion, race, and different circumstances such as disability.

In the Working Meeting of the Special Committee for the Election Bill, it was possible to capture the enthusiasm for realizing equality/equality between persons with disabilities and non-disabled persons. In the Working Meeting of the Special Committee, the Chair of the Working Meeting of the Special Committee, H.M. Lukman Edy (F-PKB), requested approval from the Special Committee on the provisions of Article 4 a. which stipulates: "Persons with disabilities who meet the requirements have equal opportunities as voters, as election participants and as election organizers" To emphasize the equality of perspective, followed by the Elucidation point of Article $4 \mathrm{a}$, namely what is meant by equality of opportunity is a condition that provides opportunities or provides access to persons with disabilities to channel their potential in all aspects of the administration of the state and society under Article 1 point 2 of Law Number 8 of 2016 (Sekretariat Jenderal DPR RI, 2017).

Furthermore, the Ratio legis regulating the political rights of persons with disabilities is also included in the 2017 General Election Law, which is an order from Law Number 7 of 2017 concerning General Elections, namely the provisions of Article 5, namely, Persons with disabilities who meet the requirements have the same opportunities as voters and are elected as candidates for DPR members, as candidates for DPD members, as candidates for President/Vice President, as candidates for DPRD members, and as candidates for members of the DPRD. Election Organizer.

The presence of Article 5 of the 2017 General Election Law, relating to Article 13 letter a, Article 75 paragraphs (1) and (2) and Article 76 of Law Number 8 of 2016 concerning Persons with Disabilities. Those who instruct the government and local governments to provide guarantees for the realization of the political rights of persons with disabilities include:

Article 13. The political rights of persons with disabilities include: 
a. Voting and being elected to public office...

Article 75 paragraph (1):

The government and local governments must ensure that persons with disabilities can participate effectively and fully in political and public life directly and through representative institutions.

Article 75 paragraph (2):

The government and local governments are obliged to guarantee the rights and opportunities for persons with disabilities to vote and be elected.

Article 76:

Persons with disabilities have the right to occupy public positions.

The provisions of Article 75 paragraph (1), paragraph (2), and Article 76 of the Law on Persons with Disabilities have formulated orders to the central government and regional governments to fulfill political rights and public positions in government. This is formulated because people with disabilities have been treated as exclusion, marginalized, or neglected in their rights in various aspects, including these political rights.

The ratio legis regulating the political rights of persons with disabilities in Law Number 7 of 2017 is an embodiment of universal international law human rights values as stated by Donelly, namely:

First, interdependent and indivisible (mutually dependent and inseparable), the enforcement and protection of human rights cannot be separated, whether those fall into the civil and political categories, rights that fall into the social and cultural categories, as well as those that fall into the collective category ( such as the political rights of persons with disabilities in Article 5 of the 2017 General Election Law, which is the embodiment of political civil rights (HSP) which are closely related to the fulfillment of other rights, namely cultural rights, economic rights, etc.). In other words, deprivation of one type of right will also affect other rights.

Second, Equal and non-discriminatory (equal and non-discriminatory): this can be seen clearly in all international law relating to human rights. This can be seen in the 2006 United Nations Convention on the Rights of the Persons with the Disability (UNCRPD). The purpose of the convention is to promote and protect and ensure the equality of fundamental rights and freedoms for all persons with disabilities and respect for the dignity of persons with disabilities as an integral part (inherent dignity). Equality and non-discrimination show that everyone has rights and cannot be discriminated against in their manifestation and protection.

Third, Both Rights and Obligations (rights and responsibilities): Human rights are both rights and obligations; namely, the state must take duties under international law to respect, protect and fulfill human rights, including protecting the political rights of persons with disabilities. The regulation of the political rights of persons with disabilities in the 2017 General Election Law is a manifestation of the implementation of state responsibilities. Its nature as a right as well as a commitment also applies at the individual level. Besides being entitled to the protection of human rights, he is also bound by the obligation not to interfere with the human rights of other individuals. Fulfillment of the political rights of persons with disabilities requires participation or participation from the community in this case in the form of awareness of the political elite to provide opportunities for persons with disabilities to be involved and sit in people's representative institutions, both DPR RI and DPRD (Provincial and Regency/City).

In essence, the presence of the 2017 General Election Law is to unravel the specific thread of protecting the political rights of persons with disabilities who have long experienced discriminatory behavior. However, the regulation of political rights for persons with disabilities in this law is only contained in Article 5 as described previously.

Judging from the Theory of Legislation, Article 5 of the General Election Law of 2017 has not described in more detail the provisions as mandated in the provisions of Article 75 paragraphs (1), (2) and Article 76 of Law Number 8 of 2016, which emphasizes the responsibility of the government and local governments to ensure the realization of the political rights of persons with disabilities, namely to respect, promote, provide protection and 
fulfillment of these political rights. The elaboration of the Law on Persons with Disabilities provisions provides delegation of political rights arrangements in the relevant laws, especially the Law on General Elections.

If you read the provisions of Article 75 paragraph (1) and paragraph (2) of Law Number 8 of 2016 concerning Persons with Disabilities requires concrete and severe steps for the government as a manifestation of government responsibility. The government referred to here, in this case, is the government in a broad sense, namely the President and the DPR RI to provide laws and regulations that can accommodate the respect, protection, and fulfillment of the political rights of persons with disabilities to be elected as members of the representative body.

Although it has not yet regulated the political rights of persons with disabilities, Law Number 8 of 2016 orders the Government in a broad sense which includes the President and DPR (Central Government), the Governor or Regent/Mayor and DPRD (Province or Regency/City) to be responsible for ensuring that persons with disabilities can "participate effectively". This means that the Government must issue policies that remove barriers for persons with disabilities to be able to participate effectively in the protection and fulfillment of their political rights to be elected as candidates for members of the DPR or DPRD. The order of the Law on Persons with Disabilities must be further elaborated in the Law on General Elections in the context of holding the 2017 General Election.

In the development of human rights, it is gradually accepted that the state is obliged to respect, fulfill, and protect all human rights in principle. Suppose it is related to the formulation of the 2017 General Election Law. In that case, the presence of the state in carrying out obligations related to human rights, according to Manfred Nowak for persons with disabilities, means that the state carries out its responsibilities to the extent of the obligation to respect human rights, referring to the obligation to avoid intervention by the state, requiring that the latter cannot be accepted under the clauses regarding limitations and relevant legal conditions (Nowak, 2003).

Respect (honor) is closely related to the ethical behavior of society. Honor or respect is a manifestation of moral rules because people believe that such behavior is under God's laws following their religion and beliefs (Islam, Catholicism, Christianity, Hinduism, Buddhism, and other faiths) (Miharso, 2009).

Through the DPR and the government, the state has not carried out the obligation to protect the political rights of persons with disabilities in the form of positive actions that can prevent violations or neglect of their political rights from being elected as candidates for members of the DPR or DPRD. The state has also not carried out its obligations to fulfill the political rights of persons with disabilities by making policies that remove barriers for them in accessing and fulfilling their political rights (Nowak, 2003).

\section{CONCLUSION}

Ratio legis regulates the political rights of persons with disabilities in Law Number 7 of 2017 concerning General Elections can be found in the Academic Paper of the Bill on the Implementation of General Elections, as well as prompted by the International Convention and the 1945 Constitution of the Republic of Indonesia and Law Number 8 of 2016 which are the reasons for the formulation of the political rights of persons with disabilities in the Law on Elections, namely:

- To realize the principle of a state of law and democracy that upholds equal rights for all without exception and eliminates discrimination and stereotypes against persons with disabilities in accessing and fulfilling their political rights to be elected as candidates for members of the DPR or DPRD;

- Objectives The formulation of political rights for persons with disabilities is to increase the participation of persons with disabilities in political life, especially to be elected as candidates for members of the DPR or DPRD (Provincial or Regency/City); 
- The purpose of formulating political rights for persons with disabilities is as an instrument of political education for the community to respect and uphold the political rights of others, including vulnerable groups such as persons with disabilities.

\section{RECOMMENDATIONS}

Based on the conclusions above, to formulate a Draft Law on Elections that is responsive to the fulfillment, protection, and enforcement of the political rights of persons with disabilities, there are several recommendations, namely:

- Should involve representatives of vulnerable groups such as persons with disabilities, should involve organizations of persons with disabilities and NGOs engaged in empowering and advocating the rights of persons with disabilities and experts relevant to disability. They must be invited because it relates to the aspirations of vulnerable groups (persons with disabilities. They better understand the problems faced by groups of people with disabilities, including the neglect of their rights, including political rights;

- DPR and the Government must be fair in formulating and determining vulnerable groups entitled to special treatment/affirmative action so that the Law on General Elections does not cause discrimination against persons with disabilities to protect, enforce and fulfill their political rights;

- Protection, enforcement, and fulfillment of political rights for persons with disabilities will be more effective through special treatment mechanisms in allocating special seats. Through this mechanism, (Political parties must give a minimum quota of $5 \%$ for Persons with Disabilities to be elected as candidates for members of the DPR or DPRD (Provincial or Regency/City).

\section{REFERENCES}

1. Asshidiqie, J. 2012. Hukum Tata Negara and Pilar-Pilar Demokrasi. Jakarta: Sinar Grafika.

2. Fuady, M. (2010). Konsep Negara Demokrasi. Bogor: Refika Aditama.

3. Handoyo, B. (2009). Hukum Tata Negara Indonesia Menuju Konsilidasi Sitem Demokrasi. Bandung: Univesitas Atmajaya Yogyakarta.

4. Kansil, C. (1985). Hukum Tata Pemerintahan Indonesia. Jakarta: Ghalia Indonesia.

5. Marzuki, P. (2005). Penelitian Hukum. Jakarta: Prenada Media.

6. Miharso, V. 2009. Perjuangan Hak-Hak Sipil di Amerika and Implikasinya Bagi Indonesia (Membongkar Pemikiran Marthin Luther King Jr. and Malcolm X). Yogyakarta: Sekolah Pasca Sarjana UGM.

7. Nowak, M. (2003). Pengantar Pada Rezim HAM Internasional. Jakarta: Kementerian Hukum and HAM Republik Indonesia.

8. Rauf, M. (1998). Demokrasi and Demokratisasi: Penjajakan Theoritis untuk Indonesia, dalam Menimbang Masa Depan Orde Baru. Jakarta: Mizan Lab IImu Politik FISIP UI, 1998.

9. Sekretariat Jenderal DPR RI. (2017). Risalah Rapat Kerja Dewan Perwakilan Rakyat RI: Pansus Rancangan Undang-Undang Tentang Penyelenggaraan Pemilu Tahun Sidang 2016-2017. Jakarta: Dewan Perwakilan Rakyat Indonesia.

10. Soemadiningrat, O. (2002). Rekonseptualisasi Hukum Adat Kontemporer. Bandung: Alumni Bandung.

11. Sumantri, S. (1969). Demokrasi Pantjasila and Implementasinya Menurut/Dalam Undang-Undang Dasar 1945. Bandung: Alumni.

12. William, N. (1973). American Pluralism. New York: Harper and Row. 